\title{
Comprehensive Newborn Care: a Bibliometric Literature Review
}

Tarciane Marinho Albuquerque ${ }^{1}$, Anna Tereza Alves Guedes ${ }^{2}$, Nathanielly Cristina Carvalho de Brito Santos ${ }^{3}$, Neusa Collet ${ }^{4}$, Altamira Pereira da Silva Reichert ${ }^{5}$

\section{Abstract}

Objective: To analyse the scientific production of comprehensive newborn health care in primary care.

Method: A bibliometric study with a quantitative approach using a sample consisting of 27 studies (two from the Virtual Health Library and 25 from PUBMED) published between 2005 and 2015.

Results: The highest number of publications on this subject were published in 2010, and the country with the most publications was the United States. Comprehensive newborn care was summarised and presented in the form of a concept map.

Conclusions: The bibliometric indicators showed that perinatal care must be provided in primary care; however, there were gaps in the scientific literature regarding approaches related to this care. This work is expected to contribute by increasing health professionals' understanding of comprehensive newborn care by disseminating scientific production and promoting discussion on the subject, thereby reducing child mortality.

\section{Introduction}

In the early days of a child's life, he/she is considered potentially vulnerable to disease. Therefore, it is essential to adequately monitor the newborn and to identify early risk factors during this period [1, 2].

Data from the World Health Organization (WHO) [3] showed that approximately 16 million children died before reaching their fifth birthday in 2015. Most deaths were due to causes considered preventable
1 Nurse, Masters in Nursing, Postgraduate Nursing Programme, Federal University of Paraíba (Universidade Federal da Paraíba, UFPB). João Pessoa, Paraíba, Brazil.

2 Undergraduate student, UFPB. João Pessoa, Paraíba, Brazil.

3 Nurse, PhD Student, Postgraduate Nursing Programme, UFPB. João Pessoa, Paraíba, Brazil.

4 Nurse, PhD in Nursing, Ribeirão Preto School of Nursing, University of São Paulo (Universidade de São Paulo); Professor, Postgraduate Nursing Programme, UFPB. João Pessoa, Paraíba, Brazil.

5 Nurse, PhD in Child and Adolescent Health, Federal University of Pernambuco (Universidade Federal de Pernambuco); Professor, Postgraduate Nursing Programme, UFPB. João Pessoa, Paraíba, Brazil.

\section{Contact information:}

Tarciane Marinho Albuquerque.

” tarci_marinho@hotmail.com

\section{Keywords}

Comprehensive Health Care; Newborn; Primary Health Care; Bibliometric Indicators. 
by primary care, including diseases such as pneumonia, diarrhoea and malaria. The first month, the first week and the first hours of life are the most critical for a baby's survival because approximately one million newborns die on their day of birth and approximately 2.8 million die during the first 28 days. Neonatal mortality is a worldwide public health problem and therefore a health care indicator for the perinatal period [4].

In addition to the $\mathrm{WHO}$, other international organisations, such as the United Nations Children's Fund (UNICEF) and other non-governmental organisations, have paid special attention to child health to ensure comprehensive monitoring and achieve a reduction in mortality through changes in health care to meet the millennium development goals (MDGs) [1].

To help reduce infant mortality in Brazil and to achieve and maintain the MDGs, the Ministry of Health (Ministério da Saúde-MS) has developed a number of policies and manuals to guide health professionals' actions, especially those who are on the front line of care during this fragile stage of life. The primary implemented guides include the Neonatal Integrated Management of Childhood Illness (IMCI), the Child Health Handbook, version 2013, the Agenda for Commitment to Comprehensive Child Health and Reduction of Infant Mortality, and Newborn Health Care: A Guide for Health Professionals [5].

Weaknesses in the implementation of these policies in primary care at the beginning of children's lives can have negative consequences on growth and development. These consequences include developmental delays, poor school performance, depression, violent behaviour, maintenance of mortality rates and high rates of chronic disease that interrupt the child's development into a healthy and economically active adult. These issues indicate that the MDGs have not been met and cause an imbalance in the country's economic level $[6,7]$.
Due to the lack of studies focused on health indicators specific to comprehensive newborn care (specifically during the perinatal period) that aim to guide primary care health professionals' actions, the main purpose of this bibliometric study is to analyse scientific production on comprehensive newborn health care in primary care with an emphasis on the identification of empirical health indicators. This study should contribute to the development of a data collection instrument for use in the first home visit for the newborn.

\section{Methods}

This study is a bibliometric study with a quantitative approach. This study type is often used to evaluate trends and patterns in specific scientific fields. This type of study has been employed over the years to characterise scientific production regarding both the most cited articles and classic citations within a journal or among the same specialties [8].

Recently, concerted efforts have been made to analyse the proportion and quality of publications on the most concerning diseases and to identify gaps in research in different fields of knowledge used by scientific authorities to support important decisions $[9,10]$.

To select publications on comprehensive newborn care, the following national and international digital literature databases were used: PUBMED, the Theses and Dissertations Portal of the Brazilian Federal Agency for the Support and Evaluation of Graduate Education (Coordenação de Aperfeiçoamento de Pessoal de Nível Superior-CAPES) and the Virtual Health Library (VHL). A journal search in these databases was performed using health terminology available in the Medical Subject Headings (MeSH) and Descriptors in Health Sciences (DeCS), which are used as the standard and unified language for indexing scientific studies and journals and which enable searching at various levels of specificity. 
Data were collected between January and March, 2015. The following descriptors were used: Newborn or Recém-nascido; Comprehensive Health Care or Atenção Integral à Saúde; Primary Health Care or Atenção primária à saúde. The terms were separated by the Boolean operator "AND" and crossreferenced as appropriate. The following inclusion criteria were used for sample selection: full articles available, focused on the subject of interest, published in either English or Portuguese and published during the last eleven years (2005-2015).

The search produced 361 studies after filtering according to the established criteria. The titles and abstracts were carefully reviewed, resulting in the exclusion of 334 publications that did not cover the proposed subject. The final sample consisted of 27 studies. These studies were organised, saved into folders, and named according to the digital library in which they were located.

A data collection form was used to facilitate the analysis of the selected studies, followed by importation into Microsoft Office Excel software version 2013 to generate a database with variables that enabled descriptive statistical analysis with frequency distributions in absolute numbers and percentages. The results were represented in charts and tables according to the items that characterised scientific production, such as journal name, year of publication, country of the author's institutional affiliation, professional training of the principal authors, Journal Citation Reports (JCR), descriptors/keywords and empirical indicators.

The concept map methodology was used to organise the terms and categorise the relationships between the concepts connected by the empirical health indicators related to comprehensive newborn health care. CMap Tools version 5.03 (developed and freely distributed by the Institute for Human Machine Cognition of the University of West Florida) was used. This tool allows the user to construct, navigate, share and criticise knowledge models represented by concept maps. It is an evaluative tool that facilitates the organisation of knowledge and promotes experiences that provoke reflection, the search for understanding and information processing, thereby facilitating learning [11].

The aim of this study was to identify affinities between indicators of comprehensive newborn heath care based on their incidence among studies and their focus as the subject of the studies. Empirical indicators are criteria and/or experimental conditions that are used to observe or measure theoretical concepts that serve as a basis for given practices to identify situations considered normal or expected, thereby making it possible to prevent health problems [12]. The indicators were grouped according to a systematic and summarised organisation that was not hierarchically based on the identification of relationships by conceptual thematic affinities.

\section{Results}

The sample comprised 27 studies on comprehensive newborn health care in Primary Health Care $(\mathrm{PHC})$; two of the studies were from the $\mathrm{VHL}$, and 25 were from PUBMED. No study was obtained from the CAPES Portal databases after analysing the relevance of the topic. Figure 1 shows that the greatest number of publications were published in 2010 (seven studies, 25.9\%), followed by six studies in 2011 (22.2\%).

Figure 1: Distribution of scientific production on comprehensive newborn health care according to year of publication. João Pessoa, state of Paraíba (PB), Brazil, 2005 to 2015.

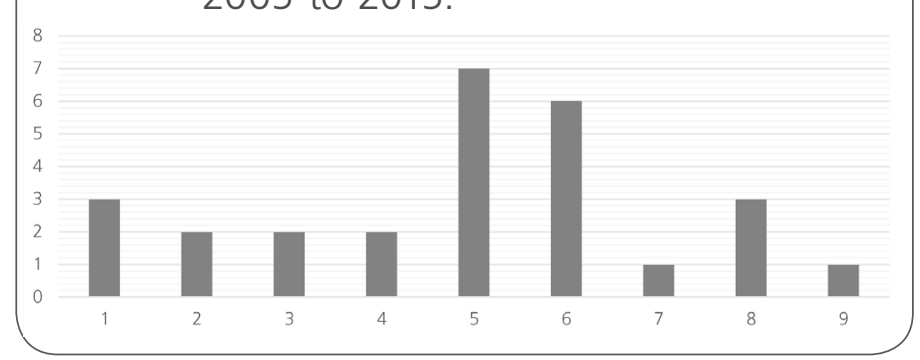


Table 1 shows the country of the author's institutional affiliation. The United States was the most prominent country, with eight studies $(29.6 \%)$, followed by Brazil with five studies (18.5\%). Notably, only one institution had more than one publication included in the study.

Table 1. Distribution of scientific literature on comprehensive newborn care according to country of the author's institutional affiliation. João Pessoa, PB, Brazil, 2005 to 2015.

\begin{tabular}{|c|c|c|}
\hline \multirow{2}{*}{$\begin{array}{c}\text { Country/author's institutional } \\
\text { affiliation }\end{array}$} & \multicolumn{2}{|c|}{$\mathrm{N}=27$} \\
\hline & $n$ & $\%$ \\
\hline \multicolumn{3}{|l|}{ Australia } \\
\hline The University of Queensland & 1 & 3.7 \\
\hline $\begin{array}{l}\text { The University of Queensland Centre for } \\
\text { Clinical Research }\end{array}$ & 1 & 3.7 \\
\hline Murdoch Childrens Research Institute & 1 & 3.7 \\
\hline University of Melbourne & 1 & 3.7 \\
\hline \multicolumn{3}{|l|}{ South Africa } \\
\hline University of Cape Town & 1 & 3.7 \\
\hline \multicolumn{3}{|l|}{ Brazil } \\
\hline Federal University of Rio Grande do Sul & & 3.7 \\
\hline Federal University of Bahia & 1 & 3.7 \\
\hline Paulista School of Medicine & 1 & 3.7 \\
\hline Fluminense Federal University & 1 & 3.7 \\
\hline $\begin{array}{l}\text { "Júlio de Mesquita Filho" Paulista State } \\
\text { University }\end{array}$ & 1 & 3.7 \\
\hline \multicolumn{3}{|l|}{ Canada } \\
\hline The University of Manitoba & 1 & 3.7 \\
\hline Memorial University of Newfoundland & 1 & 3.7 \\
\hline \multicolumn{3}{|l|}{ Spain } \\
\hline Servicio Madrileño de Salud & 1 & 3.7 \\
\hline \multicolumn{3}{|l|}{ United States } \\
\hline Columbia University & 2 & 7.4 \\
\hline Medical College of Wisconsin & 1 & 3.7 \\
\hline Seattle Children's Research Institute & 1 & 3.7 \\
\hline Robert Wood Johnson Medical School & 1 & 3.7 \\
\hline Hospital Corporation of America & 1 & 3.7 \\
\hline University of Virginia & 1 & 3.7 \\
\hline $\begin{array}{l}\text { University of Utah Department of } \\
\text { Pediatrics }\end{array}$ & 1 & 3.7 \\
\hline
\end{tabular}

\begin{tabular}{|c|c|c|}
\hline \multirow{2}{*}{$\begin{array}{c}\text { Country/author's institutional } \\
\text { affiliation }\end{array}$} & \multicolumn{2}{|c|}{$\mathrm{N}=27$} \\
\hline & $\mathbf{n}$ & $\%$ \\
\hline \multicolumn{3}{|l|}{ The Netherlands } \\
\hline University Medical Centre Utrecht & 1 & 3.7 \\
\hline \multicolumn{3}{|l|}{ India } \\
\hline School of Public Health & 1 & 3.7 \\
\hline \multicolumn{3}{|l|}{ Lithuania } \\
\hline Kaunas University of Medicine & 1 & 3.7 \\
\hline \multicolumn{3}{|l|}{ Nigeria } \\
\hline University of Benin Teaching Hospital & 1 & 3.7 \\
\hline \multicolumn{3}{|l|}{ Pakistan } \\
\hline Aga Khan University & 1 & 3.7 \\
\hline \multicolumn{3}{|l|}{ Sweden } \\
\hline Uppsala University & 1 & 3.7 \\
\hline
\end{tabular}

Table 2 shows the distribution of the journals in which the selected studies were published. The most cited journal was Pediatrics (22.3\%), with six papers. The British Medical Journal (BMJ) had the highest impact factor, with a JCR of 16.30. The average JCR for the 19 journals among which the studies were distributed was 2.42, with a standard deviation of 3.67.

Table 2. Distribution of the scientific literature on comprehensive newborn health care according to the journal and its respective impact factor, Joao Pessoa, PB, Brazil, 2005-2015.

\begin{tabular}{|l|c|c|c|}
\hline \multicolumn{1}{|c|}{ Journal } & JCR* & \multicolumn{3}{|c}{ N=27 } \\
\cline { 3 - 4 } & $\mathbf{7 2 0 1 4}$ & & $\%$ \\
\hline $\begin{array}{l}\text { BMC† Pregnancy and } \\
\text { Childbirth }\end{array}$ & 2.19 & 1 & 3.7 \\
\hline Int J Womens Health & 0.00 & 1 & 3.7 \\
\hline BMC Psychiatry & 2.21 & 1 & 3.7 \\
\hline BMC Family Practice & 1.67 & 2 & 7.4 \\
\hline BMC Pediatrics & 1.93 & 2 & 7.4 \\
\hline BMC Public Health & 2.26 & 1 & 3.7 \\
\hline Implement Sci & 4.12 & 1 & 3.7 \\
\hline BMJł & 16.30 & 1 & 3.7 \\
\hline Indian J Public Health & 0.00 & 1 & 3.7 \\
\hline NIH Public Access & 0.00 & 1 & 3.7 \\
\hline
\end{tabular}




\begin{tabular}{|l|c|c|c|}
\hline \multicolumn{1}{|c|}{ Journal } & JCR* & \multicolumn{3}{c}{ N=27 } \\
\cline { 3 - 4 } & $\mathbf{7 2 0 1 4}$ & & $\%$ \\
\hline $\begin{array}{l}\text { Arch Pediatr Adolesc } \\
\text { Med. }\end{array}$ & 5.73 & 1 & 3.7 \\
\hline Pediatrics & 5.47 & 6 & 22.3 \\
\hline Academic Pediatrics & 2.01 & 1 & 3.7 \\
\hline Sao Paulo Med J & 0.72 & 1 & 3.7 \\
\hline Cad Saude Publica & 0.98 & 1 & 3.7 \\
\hline Medicina (Kaunas) & 0.49 & 1 & 3.7 \\
\hline Niger J Clin Pract & 0.53 & 1 & 3.7 \\
\hline SAMJ§ & 1.63 & 1 & 3.7 \\
\hline Rev Lat Am Enfermagem & 0.53 & 1 & 3.7 \\
\hline Arch Dis Child & 2.90 & 1 & 3.7 \\
\hline
\end{tabular}

*: Journal Citation Records. †: Biomed Central.

‡: British Medical Journal. §: South Africa Medical Journal

The keywords that predominately corresponded to the MeSH indexing recommendations included the descriptor "newborn", which was the most cited in the studies analysed (27) (i.e., all studies contained this descriptor), followed by primary health care (22), infant (15) and breastfeeding (10), as shown in Table 3. The latter descriptor suggests that a greater number of studies were published on breastfeeding compared to the other types of care provided during the perinatal period.

Table 3. Distribution of scientific production descriptors on comprehensive newborn health care. João Pessoa, PB, Brazil, 2005 to 2015.

\begin{tabular}{|l|c|l|l|}
\hline \multicolumn{1}{|c|}{ Keyword } & $\mathbf{n}$ & Keyword & $\mathbf{n}$ \\
\hline $\begin{array}{l}\text { Acceptance of health } \\
\text { care }\end{array}$ & 01 & Weight gain & 01 \\
\hline $\begin{array}{l}\text { Accessibility of health } \\
\text { services }\end{array}$ & 01 & Quality guarantee & 02 \\
\hline $\begin{array}{l}\text { Counselling } \\
\text { Guideline adherence }\end{array}$ & 02 & Case management & 01 \\
\hline $\begin{array}{l}\text { Patient adherence } \\
\text { Community health }\end{array}$ & 01 & High risk pregnancy & 01 \\
\hline $\begin{array}{l}\text { worker } \\
\text { Antibacterial agents }\end{array}$ & 02 & Hospitalisation & 06 \\
\hline $\begin{array}{l}\text { Breastfeeding } \\
\text { Infant food }\end{array}$ & 10 & Neonatal jaundice & 07 \\
\hline $\begin{array}{l}\text { Patient discharge } \\
\text { Sickle cell anaemia }\end{array}$ & 01 & Gestational age & 01 \\
\hline
\end{tabular}

\begin{tabular}{|c|c|c|c|}
\hline Keyword & n & Keyword & n \\
\hline $\begin{array}{l}\text { Congenital } \\
\text { abnormalities }\end{array}$ & 02 & $\begin{array}{l}\text { Respiratory tract } \\
\text { infections }\end{array}$ & 02 \\
\hline Antimalarials & 01 & Early intervention & 03 \\
\hline Social support & 01 & Traditional medicine & 01 \\
\hline Primary health care & 22 & Doctors & 01 \\
\hline Anthropometry & 01 & Megalocephaly & 02 \\
\hline Outcome assessment & 02 & Child mortality & 03 \\
\hline Risk assessment & 02 & Obesity & 01 \\
\hline Infant welfare & 02 & Obstetrics & 02 \\
\hline Bilirubin & 02 & Role of the professional & 01 \\
\hline Head & 01 & Parity & 01 \\
\hline $\begin{array}{l}\text { Maternal-child health } \\
\text { centres }\end{array}$ & 01 & Homebirth & 01 \\
\hline Death certificate & 01 & Paediatrics & 06 \\
\hline $\begin{array}{l}\text { Pregnancy } \\
\text { complications }\end{array}$ & 02 & Health personnel & 02 \\
\hline Eating behaviour & 01 & Pneumonia & 02 \\
\hline Child behaviour & 01 & Poverty & 01 \\
\hline Communication & 01 & Public policy & 01 \\
\hline $\begin{array}{l}\text { Interdisciplinary } \\
\text { communication }\end{array}$ & 01 & Vulnerable populations & 01 \\
\hline $\begin{array}{l}\text { Continuity of patient } \\
\text { care }\end{array}$ & 03 & Family Practice & 01 \\
\hline Child & 02 & Knowledge practices & 02 \\
\hline Disabled children & 03 & Preschool & 07 \\
\hline $\begin{array}{l}\text { Comprehensive health } \\
\text { care }\end{array}$ & 01 & Health care provision & 01 \\
\hline Caregivers & 02 & Primary prevention & 01 \\
\hline Outpatient care & 01 & Health programs & 01 \\
\hline Long-term care & 01 & Government programs & 01 \\
\hline Child care & 06 & Health promotion & 03 \\
\hline Intensive care & 02 & Parental Psychology & 01 \\
\hline Postpartum care & 01 & Newborn & 27 \\
\hline Prenatal care & 03 & $\begin{array}{l}\text { Referral and } \\
\text { consultation }\end{array}$ & 01 \\
\hline $\begin{array}{l}\text { Developmental } \\
\text { disabilities }\end{array}$ & 03 & $\begin{array}{l}\text { Mother-child } \\
\text { relationship }\end{array}$ & 01 \\
\hline Child development & 02 & $\begin{array}{l}\text { Doctor-patient } \\
\text { relationship }\end{array}$ & 01 \\
\hline Diarrhoea & 02 & $\begin{array}{l}\text { Parent-child } \\
\text { relationship }\end{array}$ & 01 \\
\hline $\begin{array}{l}\text { Health planning } \\
\text { directives }\end{array}$ & 01 & $\begin{array}{l}\text { Professional-family } \\
\text { relationship }\end{array}$ & 0 \\
\hline Practice directives & 04 & Risk & U \\
\hline
\end{tabular}




\begin{tabular}{|l|c|l|l|}
\hline \multicolumn{1}{|c|}{ Keyword } & $\mathbf{n}$ & Keyword & $\mathbf{n}$ \\
\hline Breathing disorders & 02 & Patient satisfaction & 01 \\
\hline Information disclosure & 01 & Family Health & 01 \\
\hline Chronic disease & 01 & Maternal health & 04 \\
\hline Brain diseases & 02 & $\begin{array}{l}\text { Neonatal and child } \\
\text { health }\end{array}$ & 01 \\
\hline Genetic diseases & 02 & Rural health & 01 \\
\hline Metabolic diseases & 02 & $\begin{array}{l}\text { Sensitivity and } \\
\text { specificity }\end{array}$ & 01 \\
\hline Patient education & 02 & Sepsis & 02 \\
\hline Health education & 01 & Community Services & 01 \\
\hline Nursing & 01 & Child health services & 02 \\
\hline
\end{tabular}

The analysis of the articles identified 625 empirical indicators that were organised to generate a concept map based on the similarity of the meaning of the terms, as shown in Figure 2.

\section{Discussion}

Brazil has established agreements to improve the quality of health care provided to mothers and newborns in primary care in an attempt to reduce the high maternal and infant mortality rates [13]. The main focus of policy guidelines for actions and care

\begin{tabular}{|l|l|l|l|}
\multicolumn{1}{|c|}{ Keyword } & $\mathbf{n}$ & Keyword & $\mathbf{n}$ \\
\hline Maternal-child nursing & 01 & Home services & 01 \\
\hline Practical nursing & 01 & Growth tables & 01 \\
\hline $\begin{array}{l}\text { Internship and } \\
\text { residency }\end{array}$ & 01 & Transfusion & 01 \\
\hline Physical examination & 01 & Lactation disorders & 01 \\
\hline Age-sensitive factors & 01 & Mental disorders & 01 \\
\hline Risk factors & 02 & Puerperal disorders & 01 \\
\hline Socioeconomic factors & 02 & Neonatal screening & 04 \\
\hline Cystic fibrosis & 01 & Pregnancy trimester & 01 \\
\hline Infant formula & 01 & Oxygen Use & 01 \\
\hline Phototherapy & 02 & Violence & 02 \\
\hline
\end{tabular}

practices to prevent disease onset for infant care is the postpartum period [14].

According to the Ministry of Health, it is necessary to use care-guiding principles to achieve comprehensive child care. These principles include planning and development of activities, providing continued care and permanent and systemised evaluation of the care for children and mothers [15]. However, this situation is only possible if health workers are properly trained [14]

The data obtained from analysing the year of publication of the studies presented in Figure 1

Figure 2: Concept map generated from the empirical indicators selected for the study - João Pessoa, PB, Brazil, 2005-2015.

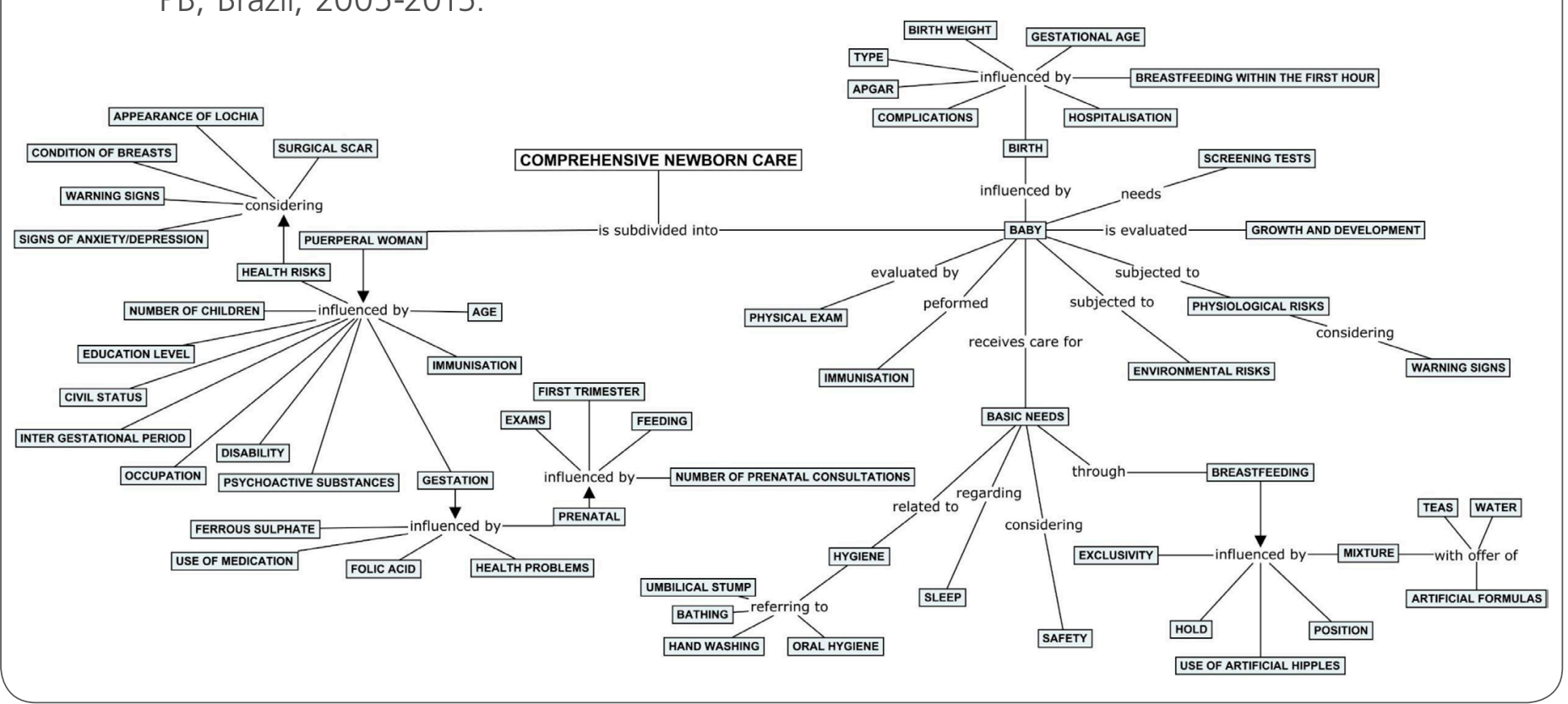


revealed a continuous number of publications that peaked in 2010 and 2011 and an absence of scientific production in the years 2007 and 2015 up to the time of data collection (March). There is a shortage of literature on this subject, which is important for reducing infant mortality, in contrast to the attempts at improvement mentioned above.

When the national and international literature on comprehensive newborn health care produced over the past 11 years is compared, the results show greater concern about the systematisation and standardisation of health professionals' actions at an international level [16]. At that level, researchers have focused on creating care guidelines, home visit instruments, consultation instruments, and specific screening tests as well as on the training of health workers and improvements in the qualifications for top-level professionals. This information systematisation is aimed at improving health actions [17].

In accordance with the above concerns, a strategy adopted by the United States ("The well-baby care" strategy) was identified that represented more than one-third of all visits by infants and small children in the country. This strategy has proven to be successful in identifying health conditions and behavioural, developmental and social issues that can have long-term effects on children's lives [18, 19]. In Canada, a similar initiative uses an instrument known as the "Rourke Baby Record" [20]. This instrument consists of four guidelines for charting well baby/child home visits from birth to five years of age.

Some of the investigated studies [21, 22], in addition to UNICEF and the WHO, agree that the home visit (HV) is an important strategy to promote universal access to prenatal and postpartum care and thus help reduce maternal and newborn mortality. In this regard, research [23] has shown that newborn care interventions based on home care can prevent 30 to $60 \%$ of newborn deaths. This point underlines the importance of home vi- sits to babies in the first week of life as a method to reduce neonatal mortality as recommended by the above-mentioned worldwide organisations.

The HV promotes positive parenting and prevents the child's exposure to stress during a critical developmental period. However, most families in countries such as Bangladesh, Malawi and Nepal receive fewer home visits than should be conducted according to evidence-based models [23-26]. Furthermore, Brazilian health professionals do not have specific instruments to guide or facilitate visits and diagnosis during their health promotion activities nor scales to facilitate their evaluation.

An analysis of the main indicators of comprehensive newborn care collected from articles published nationally and internationally during the study period revealed that this topic was subdivided into data related to maternal health and newborn health. However, it was not possible to identify publications that solely addressed the guidance given to mothers regarding the promotion of comprehensive newborn health care because the indicators were cited indirectly due to the limited coverage given to the particular conditions of mother-child health care issues.

\section{Conclusion}

The investigated bibliometric indicators reveal care practices that should be implemented during the perinatal period, with a greater focus on issues related to breastfeeding. A greater number of publications was found in international journals, with the United States accounting for the highest number of published articles on this subject.

Despite consolidated efforts, the prevailing scientific publications have gaps with regards to the approach used for comprehensive newborn care in primary care because they do not provide complete information for health professionals. For this reason, more research is needed on this subject, especially in Brazil. 
We hope that this work will expand health professionals' understanding of the importance of comprehensive newborn health care by disseminating scientific production and promoting discussion so that effective actions can be taken. However, there are some limitations to the study. For example, this study only includes research published in English and Portuguese, although the former language is the main language of scientific communication.

\section{References}

1. Welaga P, Moyer CA, Aborigo R, Adongo P, Williams J, Hodgson $A$, et al. Why are babies dying in the first month after birth? A 7-year study of neonatal mortality in Northern Ghana. Plos One. 2013; 8 (3):e58924. Available from: http://journals.plos. org/plosone/article?id=10.1371/journal.pone.0058924

2. Save the children. Surviving the first day: state of the world's mothers. Westport: Save the children; 2013. 86 p. Available from: http://www.savethechildren.org/atf/cf/\%7B9def2ebe-10ae432c-9bd0-df91d2eba74a\%7D/SOWM-FULL-REPORT 2013.PDF

3. United Nations. The Millennium Development Goals Report. New York: United Nations; 2015. 72 p. Available from: http://www.un.org/millenniumgoals/2015 MDG Report/pdf/ MDG\%202015\%20rev\%20(July\%201).pdf

4. Sabiri N, Kabiri M, Karboubi L, Bouziane A, Barkat A. Risk factors for perinatal mortality at Souissi Maternity Hospital, Rabat, Morocco. Int J Gynaecol Obstet. 2012; 119(3):285-6.

5. Araújo JP, Silva RMM, Collet N, Neves ET, Toso BRGO, Viera CS. História da saúde da criança: conquistas, políticas e perspectivas. Rev Bras Enferm. 2014; 67(6):1000-7. Available from: http://www. scielo.br/pdf/reben/v67n6/0034-7167-reben-67-06-1000.pdf

6. Reichert APS, Collet N, Eickmann SH, Lima MC. Child development surveillance: intervention study with nurses of the Family Health Strategy. Rev. Latino-am. Enfermagem. 2015; 23 (5):954-62. Available from: http://www.scielo.br/pdf/rlae/ v23n5/pt 0104-1169-rlae-23-05-00954.pdf

7. Silver $\mathrm{KL}$, Singer PA. A focus on child development. Science. 2014;345(6193):121. Available from: http://science.sciencemag. org/content/345/6193/121.full.

8. Marziale MHP. Indicators of Ibero-american scientific production [editorial]. Rev. Latino-Am. Enfermagem. 2011; 19 (4):853-4. Available from: http://www.producao.usp. br/bitstream/handle/BDPI/3625/Indicadores $\% 20 \mathrm{da} \% 20$ produ\%C3\%A7\%C3\%A30\%20cient \%C3\%ADfica\%20iberoamericana.pdf? sequence $=3 \&$ is $A$ llowed $=y$

9. McDowell DT, Glynn RW, Mortell A, Quinn F. Publication patterns on neonatal surgery over 65 years. J Pediatr Surg. 2013; 48(3):585-90. Available from: http://www.ncbi.nlm.nih. gov/pubmed/23480917

10. Quinn N, Hensey O, McDowell DT. A historical perspective of pediatric publications: a bibliometric analysis. Pediatrics. 2013; 132(3):406-12. Available from: http://pediatrics.aappublications. org/content/132/3/406.long
11. Souza NA, Boruchovitch E. Mapas conceituais: estratégia de ensino/aprendizagem e ferramenta avaliativa. Educ Rev. 2010; 26(3):195-217. Available from: http://www.scielo.br/pdf/edur/ v26n3/v26n3a10.pdf

12. Polit DF, Beck CT. Fundamentos da pesquisa em enfermagem: avaliação de evidências para a prática da enfermagem. 7 ed. Porto Alegre: Artmed; 2011.

13. Ministério da Saúde (BR). Atenção à saúde do recém-nascido. Guia para os profissionais da saúde. Brasília: Ministério da Saúde, 2011. Available from: http://www.redeblh.fiocruz.br/ media/arn v1.pdf

14. Woods DL. Improving neonatal care in district and community health facilities in South Africa. Paediatr Int Child Health. 2015; 35(3):187-91

15. Aparecida M, Gaiva M, Dias S, Carvalho V, Siqueira A. Atenção ao neonato na estratégia saúde da família: avanços e desafios para a atenção integral. Cogitare Enferm. 2012; 17(4):730-7. Available from: http://ojs.c3sl.ufpr.br/ojs/index.php/cogitare/ article/viewFile/30382/19658

16. Norlin C, Crawford MA, Bell CT, Sheng X, Stein MT. Delivery of Well-Child Care: A Look Inside the Door. Acad Pediatr. 2011; 11(1):18-26. Available from: http://www.academicpedsjnl.net/ article/S1876-2859(10)00353-0/pdf

17. Holmes ES, Santos SR, Almeida AF, Oliveira JHD, Carvalho GDA, Fônseca LCT, Costa MBS et al. Health Information Systems in the Decision-Making Process in Primary Care. International Archieves of medicine, Vol. 9 No. 2, 2016. Available from: http://imed.pub/ojs/index.php/iam/article/view/1380/1116.

18. McBride DL. New Models of Well-Child Care Visits. J Pediatr Nurs. 2014; 29(6):703-4.
Publish in International Archives of Medicine

International Archives of Medicine is an open access journal publishing articles encompassing all aspects of medical science and clinical practice. IAM is considered a megajournal with independent sections on all areas of medicine. IAM is a really international journal with authors and board members from all around the world. The journal is widely indexed and classified Q1 in category Medicine. 